\title{
Pengaruh Imbangan Protein Kasar dan Total Digestible Nutrients pada Pakan yang Berbeda Terhadap Pemanfaatan Energi Pakan pada Domba Lokal
}

\author{
D. Nugroho, A. Purnomoadi dan E. Riyanto \\ Program Studi Produksi Ternak, Fakultas Peternakan dan Pertanian, \\ Universitas Diponegoro, Semarang \\ Email : abecede_koko@yahoo.com
}

\begin{abstract}
ABSTRAK
Pemanfaatan energi pakan oleh ternak dipengaruhi oleh imbangan protein-energi di dalam pakan. Tujuan dari penelitian ini adalah untuk mengetahui imbangan protein kasar (PK) dan Total Digestible Nutrients (TDN) di dalam pakan yang efisien untuk berproduksi pada ternak domba lokal, dengan melihat kemampuan energi yang dimanfaatkan dari pakan. Domba lokal jantan sebanyak 24 ekor dengan rata-rata bobot badan awal $18 \pm 3,1 \mathrm{~kg}$ (CV 17,15\%), dirancang dengan rancangan acak lengkap (RAL) ke dalam 6 perlakuan pakan komplit : Treatment 1 (PK 18,84\% dan TDN 61,56\%), Treatment 2 (PK 16,29\% dan TDN 66,51\%), Treatment 3 (PK 19,94\% dan TDN 60,29\%; T3), Treatment 4 (PK 19,40\% dan TDN 67,31\%), Treatment 5 (PK 20,88\% dan TDN 60,47\%), Treatment 6 (PK 20,12\% dan TDN 63,05\%). Data dianalisis dengan analisis variansi. Konsumsi BK pada domba antar perlakuan menunjukkan hasil yang tidak berbeda nyata $(\mathrm{P}>0,05)$. Rata-rata konsumsi $\mathrm{BK}$ dari penelitian ini adalah 775,6 g/hari. Konsumsi energi pada setiap perlakuan tidak berbeda nyata $(\mathrm{P}>0,05)$ (rata-rata 14,27 $\pm 1,7 \mathrm{MJ} /$ hari). Pengaruh imbangan PK dan TDN pakan yang berbeda pada jumlah energi yang tercerna pada setiap perlakuan tidak berbeda nyata $(\mathrm{P}>0,05)$. Rata-rata energi termetabolis pada domba lokal dalam penelitian ini adalah 6,28 $\pm 0,9 \mathrm{MJ} / \mathrm{hari}(\mathrm{P}>0,05)$. Simpulan dari penelitian ini adalah imbangan PK dan TDN pakan yang berbeda pada penelitian ini tidak memberikan pengaruh terhadap pemanfaatan energi dan pertambahan bobot badan (PBBH) domba lokal.
\end{abstract}

Kata Kunci: domba, imbangan PK dan TDN, pemanfaatan energi pakan

\section{The Effects of Difference Ratio of Dietary Crude Protein and Total Digestible Nutrients on The Energy Utilization of Native Sheep}

\begin{abstract}
Energy utilization is affected by protein-energy balance in the feed. The purpose of this study was to determine the optimum balance of crude protein (CP) and total digestible nutrients (TDN) in a feed efficiency on the native sheep, by looking at the ability of the utilization of energy from the feed. 24 male native sheep with an average of initial body weight around $18 \pm 3.1 \mathrm{~kg}(\mathrm{CV}=17.15 \%)$, were used and designed with a completely randomized design (CRD) into 6 dietary treatments of complete feed: Treatment 1 (CP $18.84 \%$ and $61.56 \%$ TDN), Treatment 2 (CP $16.29 \%$ and $66.51 \%$ TDN), Treatment 3 (CP 19.94\% and 60.29\% TDN), Treatment 4 (CP 19.40\% and 67.31\% TDN), Treatment 5 (CP 20.88\% and 60.47\% TDN), Treatment 6 (CP 20.12\% and 63.05\% TDN). Data were analyzed by analysis of variance. Results of DM intake between treatments were not significantly different $(\mathrm{P}>0.05)$. The average intake of DM of the study was $775.6 \mathrm{~g} /$ day. Energy intake in each treatment was not significantly different $(\mathrm{P}>0.05)(14.27 \pm 1.7 \mathrm{MJ} /$ day $)$. Different ratio of $\mathrm{CP}$ and TDN on digested amount of energy in each treatment were not significantly different $(\mathrm{P}>0.05)$. Average metabolized energy in native sheep in this study was $6.28 \pm 0.9 \mathrm{MJ} /$ day $(\mathrm{P}>0.05)$. Conclusion from this research is the different balance of CP and TDN in this study do not have any impact on energy utilization and body weight gain (ADG) of native sheep.
\end{abstract}

Key words: sheep, ratio of CP and TDN, energy feed utilization 


\section{PENDAHULUAN}

Produktivitas ternak sangat dipengaruhi oleh jumlah pakan dan nutrien yang dapat dimanfaatkan oleh ternak. Kualitas nutrien yang dilihat dari aspek energi yang terkandung di dalam pakan yang dikonsumsi, tidak semuanya dimanfaatkan oleh ternak, ada termanfaatkan, sebagian lainnya terbuang melalui feses, urin, gas metan dan panas (Tillman et al., 1984). Ternak menyerap energi di dalam pakan terutama untuk hidup pokok, dan apabila masih ada kelebihan energi akan digunakan untuk produksi, namun sebagian energi diserap di dalam tubuh akan dikonversi menjadi panas tubuh (Gatenby, 1986). Pemanfaatan energi dipengaruhi oleh kualitas pakan yang dikonsumsi, termasuk imbangan protein kasar (PK) dan Total Digestible Nutrients (TDN) atau energi. Kebutuhan rasio protein-energi pakan lebih besar pada ternak ruminansia muda yang sedang tumbuh dengan cepat (Soeparno, 2005). Rasio protein-energi yang sinkron akan menunjukkan efisiensi fermentasi yang optimal, dalam hal ini energi pakan yang dimanfaatkan untuk proses tersebut akan optimal pula (Ginting, 2005). Sehingga perlu dikaji seberapa besar energi yang mampu dimanfaatkan oleh ternak yang diberi pakan dengan imbangan PK dan TDN yang berbeda. Tujuan dari penelitian ini adalah untuk mengetahui imbangan PK dan TDN di dalam pakan yang efisien untuk berproduksi pada ternak domba lokal, dengan melihat kemampuan energi yang dimanfaatkan dari pakan. Manfaat dari penelitian ini adalah untuk bahan referensi dalam penggunaan komposisi pakan sehingga pemanfaatan energi di dalam pakan dapat optimal untuk berproduksi. Hipotesis dari penelitian ini adalah imbangan PK dan TDN pakan yang berbeda memberikan pengaruh terhadap pemanfaatan energi domba lokal jantan.

\section{MATERI DAN METODE}

\section{Materi Penelitian}

Penelitian tentang pengaruh pemberian pakan dengan imbangan protein kasar dan Total Digestible Nutrients yang berbeda terhadap pemanfaatan energi domba lokal sebanyak 24 ekor dengan bobot badan (BB) awal $18 \pm 3,1 \mathrm{~kg}(\mathrm{CV}=17,15 \%)$, dan umur 5-7 bulan, dilakukan pada bulan Oktober sampai Desember 2008 di Laboratorium Ilmu Ternak Potong dan Kerja Fakultas Peternakan Universitas Diponegoro, Semarang. Penelitian ini menggunakan domba lokal jantan dengan 6 perlakuan pakan yang berbeda imbangan PK dan TDNnya. Komposisi Pakan dapat dilihat pada Tabel 1 .

Ternak diberi pakan berupa pelet dengan komposisi bahan pakan yang berbeda. Pelet diberikan 2 kali sehari yaitu pada pukul 07.00 dan pukul 15.00. Air diberikan secara ad libitum setiap hari. Kandungan nutrisi pakan tercantum pada Tabel 2.

Peralatan yang digunakan adalah tempat pakan dan air minum, timbangan untuk menimbang ternak, pakan, peralatan untuk pembuatan pakan komplit, kandang metabolik untuk koleksi feses dan urine dan peralatan untuk koleksi feses dan urine. Energi yang keluar dalam bentuk gas metan diukur dengan alat $\mathrm{CH}_{4}$ Analyzer yang dilengkapi alat pengukur volume aliran udara (L/min) Airflow meter STEC, dengan merek dagang Horiba Ltd, Japan.

\section{Metode Penelitian}

Penelitian ini dirancang dengan Rancangan Acak Lengkap (RAL) kedalam 6 (enam) perlakuan ransum komplit. Enam imbangan PK dan TDN perlakuan ransum komplit dapat dilihat pada Tabel 3. Prosedur penelitian dilakukan melalui 4 tahap yaitu : tahap persiapan, adaptasi, pendahuluan dan perlakuan.

Persiapan yang dilakukan adalah persiapan pakan, kandang dan alat, serta domba penelitian. Persiapan pakan meliputi pengadaan bahan pakan, analisis kandungan 
Tabel 1. Komposisi Bahan Pakan.

\begin{tabular}{|c|c|c|c|c|c|c|}
\hline \multirow[b]{2}{*}{ Komposisi ${ }^{*}$} & \multicolumn{6}{|c|}{ Treatment } \\
\hline & T1 & $\mathrm{T} 2$ & T3 & $\mathrm{T} 4$ & $\mathrm{~T} 5$ & T6 \\
\hline & & & $\ldots . . .(\%$ & & 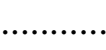 & $\ldots \ldots$ \\
\hline Tepung daun lamtoro & 6,97 & 7,08 & 7,05 & 6,94 & 6,95 & 7,02 \\
\hline Dedak padi & 3,90 & 65,31 & 56,30 & 0,97 & 0,97 & 45,17 \\
\hline Ampas bir & 34,31 & 8,20 & 19,31 & 50,29 & 43,30 & 31,54 \\
\hline P. purpureum & 12,17 & 12,36 & 12,32 & 12,13 & 12,14 & 12,27 \\
\hline Singkong & 42,66 & 7,05 & 5,02 & 29,66 & 36,63 & 4,00 \\
\hline
\end{tabular}

Keterangan: * berdasarkan $100 \%$ bahan kering

Tabel 2. Kandungan Nutrisi pada Pakan Perlakuan.

\begin{tabular}{lrrrrrr}
\hline \hline Kandungan nutrisi & T1 & T2 & T3 & T4 & T5 & T6 \\
\hline Bahan kering (\%) & 90,86 & 89,95 & 90,25 & 89,41 & 88,38 & 88,04 \\
Protein kasar (\%) & 18,84 & 16,29 & 19,94 & 19,40 & 20,88 & 20,12 \\
TDN (\%) & 61,56 & 66,51 & 60,29 & 67,31 & 60,47 & 63,05 \\
Energi (MJ/g) & 17,45 & 17,96 & 18,04 & 18,74 & 18,53 & 19,60 \\
\hline
\end{tabular}

Keterangan: " berdasarkan $100 \%$ bahan kering.

Tabel 3. Rasio Protein Kasar dan TDN di dalam Pakan Perlakuan.

\begin{tabular}{lrrrrrr}
\hline \hline & T1 & T2 & T3 & T4 & T5 & T6 \\
\hline Protein Kasar (\%) & 18,84 & 16,29 & 19,94 & 19,4 & 20,88 & 20,12 \\
TDN (\%) & 61,56 & 66,51 & 60,29 & 67,31 & 60,47 & 63,05 \\
\hline
\end{tabular}

nutrien bahan pakan, penyusunan pakan komplit dan pembuatan pelet. Cara pembuatan pakan komplit berbentuk pelet adalah semua bahan pakan digiling, masingmasing bahan pakan ditimbang sesuai dengan proporsinya, dicampur, ditambah air secukupnya kemudian dicetak dengan mesin pelet dan setelah itu dijemur. Kandang dan peralatan yang akan digunakan untuk penelitian dipersiapkan dan dibersihkan.

Tahap adaptasi dilakukan dengan mengadaptasikan ternak domba terhadap lingkungan dan pakan penelitian. Pakan penelitian diberikan sedikit demi sedikit secara bertahap sehingga domba dapat mengkonsumsi seluruh pakan penelitian. Pada tahap ini juga dilakukan pemberian obat cacing agar domba penelitian tidak terpengaruh oleh parasit cacing.

Tahap pendahuluan merupakan tahap lanjutan setelah tahap adaptasi. Memasuki tahap pendahuluan, domba dibagi secara acak kedalam 6 perlakuan pakan komplit dan penempatan dalam kandang. Tahap pendahuluan berlangsung selama 7 hari dan bertujuan untuk menghilangkan sisa-sisa pakan dalam saluran pencernaan dari waktu sebelumnya. Pada tahap ini juga diamati kemampuan ternak mengkonsumsi pakan. Pada akhir tahap pendahuluan dilakukan penimbangan bobot badan ternak untuk mendapatkan bobot badan awal penelitian.

Tahap perlakuan merupakan tahap akhir, pakan diberikan sebanyak $4 \%$ dari bobot badan ternak (sesuai kemampuan ternak) dan pemberiannya dilakukan dua kali sehari yaitu setiap pagi (pukul 7:00) dan sore (pukul 15:00) hari, sedangkan air minum diberikan secara ad libitum. Sebelum pemberian pakan dan air minum di pagi hari dilakukan penimbangan sisa pakan. Domba ditimbang seminggu sekali untuk menyesuaikan jumlah ransum yang diberikan.

Pengambilan sampel feses untuk analisis proksimat serta sampel urin untuk analisis protein pada masing-masing domba dilakukan selama satu minggu. Cara koleksi feses dan urin adalah domba ditempatkan dalam kandang metabolik selama 7 hari. 
Setiap hari dilakukan penimbangan feses dan urin yang terkumpul, feses yang ditampung disemprot dengan $\mathrm{H}_{2} \mathrm{SO}_{4} 20 \%$ secara merata untuk mencegah penguapan N. Urin yang berhasil dikoleksi setiap hari ditempatkan dalam jirigen yang telah diisi $\mathrm{H}_{2} \mathrm{SO}_{4} 20 \%$ sebanyak $25 \mathrm{ml}$ (hingga $\mathrm{pH}$ menjadi 3, untuk mencegah penguapan $\mathrm{N}$ dan menghentikan aktivitas mikrobia). Cara pengambilan sampel feses adalah feses hasil koleksi selama 7 hari dicampur hingga merata, kemudian diambil sampel sebanyak $300 \mathrm{~g}$, dijemur, kemudian digiling dan dibawa ke laboratorium untuk analisis proksimat dan analisis energi (kalori) dalam feses. Cara pengambilan sampel urin yang telah di beri $\mathrm{H}_{2} \mathrm{SO}_{4}$ hingga $\mathrm{pH}$ turun dibawah 3 adalah hasil koleksi urin selama 7 hari diaduk hingga rata dan diambil sampel sebanyak 20 g, kemudian di oven pada suhu $60^{\circ} \mathrm{C}$, hingga $\mathrm{pH}$ dibawah 3, untuk analisis energi (kalori).

Energi dalam pakan, feses dan urin diukur dengan Bomb Calorymeter. Energi yang keluar dalam bentuk gas metan diukur dengan Face Mask Methods yang dihubungkan dengan alat pengukur konsentrasi $\mathrm{CH}_{4}$ (ppm) $\left(\mathrm{CH}_{4}\right.$ Analyzer, Horiba Ltd, Japan) yang dilengkapi dengan pengukur volume aliran udara (L/min) (Airflow meter, STEC, Horiba Ltd, Japan). Total gas metan yang keluar didapatkan dari perkalian konsentrasi dengan volume gas yang mengalir. Pengukuran dilakukan selama 10 menit dengan interval 3 jam dalam waktu 2 x 24 jam setelah total koleksi. Hasil keluaran energi gas metan harian (MJ/hari) didapatkan dari rataan keluaran harian (1/d) dikalikan dengan 0,040 (MJ/l). Metode pengukuran didasarkan pada petunjuk Kawashima et al. (2001).

Parameter yang diamati terdiri dari konsumsi BK, energi dalam feses, energi dalam urine, energi tercerna dan energi teretensi. Cara perhitungan parameter tersebut adalah sebagai berikut:

$$
\begin{aligned}
\text { Konsumsi BK (kg/hari) } & \\
= & \text { Konsumsi pakan (kg/hari) x \% BK } \\
& \text { Pakan }
\end{aligned}
$$

\author{
Energi Bruto Konsumsi (J/hari) \\ $=$ Konsumsi $\mathrm{BK}$ pakan $(\mathrm{kg} / \mathrm{hari}) \mathrm{x}$ \\ energi bruto pakan $(\mathrm{J} / \mathrm{kg})$ \\ Energi Feses (J/hari) \\ $=$ Feses $(\mathrm{kg} / \mathrm{hari}) \mathrm{x}$ energi feses $(\mathrm{J} / \mathrm{kg})$ \\ Energi Urin (J/hari) \\ $=$ Urin $(\mathrm{kg} / \mathrm{hari}) \mathrm{x}$ energi urin $(\mathrm{J} / \mathrm{kg})$ \\ Energi Metan ( $\mathrm{J} /$ hari) \\ $=$ Keluaran gas metan $(1 /$ hari $) \times 40(\mathrm{~J} / \mathrm{l})$ \\ Energi tercerna (J/hari) \\ $=$ Energi bruto konsumsi (J/hari) - \\ energi feses ( $\mathrm{J} / \mathrm{hari})$ \\ Energi metabolis (J/hari) \\ $=$ Energi bruto konsumsi (J/hari) - \\ energi feses ( $\mathrm{J} / \mathrm{hari})$ - energi urin \\ (J/hari) - energi gas (J/hari)
}

\section{Analisis Data}

Data hasil penelitian dianalisis dengan analisis variansi dan korelasi. Perbedaan yang terjadi diuji dengan uji wilayah ganda Duncan (Steel dan Torrie, 1991).

\section{HASIL DAN PEMBAHASAN}

Hasil penelitian mengenai 6 perlakuan pakan yang memiliki imbangan PK dan TDN yang berbeda terhadap beberapa parameter yang diamati, ditampilkan pada Tabel 4.

\section{Konsumsi Bahan Kering (BK)}

Hasil analisis statistik menunjukkan bahwa konsumsi BK pada domba antar perlakuan tidak berbeda nyata $(\mathrm{P}>0,05)$. Hal ini berarti imbangan PK dan TDN yang berbeda pada pakan perlakuan, tidak berpengaruh terhadap konsumsi BK. Hal ini dikarenakan bahan pakan penyusun dan bentuk fisik pakan perlakuan sama. Alasan tersebut sesuai dengan pendapat Mubarok (2008) bahwa keseragaman sifat fisik pakan dapat menyebabkan palatabilitas pakan sama. Menurut Pond et al. (1995) faktor pakan yang mempengaruhi tingkat konsumsi, antara lain adalah ukuran partikel dan palatabilitas bahan pakan. 
Tabel 4. Pengaruh Imbangan Protein Kasar dan Total Digestible Nutrients yang Berbeda terhadap Pemanfaatan Energi Pakan Harian Per Ekor pada Domba Lokal.

\begin{tabular}{lrrrrrrr}
\hline \hline Parameter & T1 & T2 & T3 & T4 & T5 & T6 & Ket \\
\hline Bobot Badan Awal (kg) & 18 & 17 & 18 & 21 & 18 & 17 & \\
PBBH (g) & 73,05 & 73,86 & 60,06 & 71,43 & 64,12 & 45,45 & ns \\
Konsumsi & & & & & & & \\
$\quad$ BK (g/hari) & 795,0 & 692,2 & 744,4 & 931,0 & 745,9 & 745,3 & ns \\
$\quad$ Energi (MJ/hari) & 13,88 & 12,43 & 13,43 & 17,44 & 13,82 & 14,61 & ns \\
Ekskresi & & & & & & & \\
$\quad$ Feses (MJ/hari) & 7,29 & 5,74 & 6,65 & 8,51 & 7,67 & 5,99 & ns \\
$\quad$ Urin (MJ/hari) & 0,19 & 0,27 & 0,32 & 0,31 & 0,23 & 0,29 & ns \\
$\quad$ Methan (MJ/hari) & $0,73^{\mathrm{b}}$ & $0,46^{\mathrm{c}}$ & $0,49^{\mathrm{c}}$ & $1,31^{\mathrm{a}}$ & $0,68^{\mathrm{b}}$ & $0,81^{\mathrm{b}}$ & $\mathrm{s}$ \\
Tercerna & & & & & & & \\
$\quad$ BK (g/hari) & 490,3 & 426,2 & 431,9 & 609,9 & 439,4 & 454,0 & $\mathrm{~ns}$ \\
$\quad$ Energi (MJ/hari) & 6,59 & 6,69 & 6,78 & 8,94 & 6,15 & 8,62 & $\mathrm{~ns}$ \\
$\quad$ Kecernaan energi (\%) & 46,75 & 54,04 & 50,27 & 51,39 & 44,63 & 58,74 & $\mathrm{~ns}$ \\
Termetabolis & & & & & & & \\
$\quad$ Energi (MJ/hari) & 5,66 & 5,96 & 5,97 & 7,32 & 5,24 & 7,52 & $\mathrm{~ns}$ \\
$\quad$ \% terhadap Energi Bruto & 40,38 & 47,87 & 44,35 & 42,22 & 38,02 & 51,25 & $\mathrm{~ns}$ \\
\hline Ketergan
\end{tabular}

Keterangan : Superskrip yang berbeda pada baris yang sama menunjukkan perbedaan yang nyata $(\mathrm{P}<0,05) ;{ }^{\mathrm{ns}}$ adalah non signifikan dan ${ }^{\mathrm{s}}$ adalah signifikan dengan alfa $(\alpha)$ sebesar 0,05 .

Rata-rata konsumsi BK dari semua perlakuan pada penelitian ini adalah $775,6 \pm 82,8 \mathrm{~g}$ /hari (setara dengan $3,7 \%$ dari rata-rata bobot badan ternak selama pemeliharaan). Konsumsi BK pakan pada penelitian ini lebih tinggi dari konsumsi BK yang dinyatakan oleh Devendra dan McLeroy (1982), bahwa konsumsi BK pada domba sebesar 3\% dari bobot badan. Hal ini menunjukkan kemampuan konsumsi domba penelitian lebih baik, dikarenakan palatabilitas pakan yang baik. Apabila konsumsi BK penelitian ini dibandingkan dengan hasil penelitian Lestari et al. (2003) dengan konsumsi pakan domba lokal mampu mencapai 4,45\% dari bobot badan, konsumsi BK penelitian ini lebih kecil. Kondisi ini diduga dikarenakan TDN (energi) pada penelitian ini $(60,29-67,31 \%)$ lebih besar daripada penelitian Lestari et al. (2003), yaitu sebesar 55,55-58,07\%. Kondisi ini kemungkinan disebabkan oleh kebutuhan energi ternak yang telah terpenuhi sehingga konsumsi pakan akan berhenti (Parakkasi, 1999).

\section{Konsumsi Energi}

Konsumsi energi dari semua perlakuan dapat dilihat pada Tabel 4. Hasil pengamatan terhadap konsumsi energi pakan secara keseluruhan pada domba lokal jantan tidak menunjukkan perbedaan yang nyata $(\mathrm{P}>0,05)$. Hal ini dimungkinkan karena konsumsi BK domba pada semua perlakuan tidak berbeda nyata $(\mathrm{P}>0,05)$, dan pakan perlakuan mengandung energi yang relatif sama (rata-rata 18,39 $\pm 0,75 \mathrm{MJ} / \mathrm{g}$ ). Rata-rata konsumsi energi pada penelitian ini $(14,27 \pm 1,7 \mathrm{MJ} / \mathrm{hari})$ lebih tinggi daripada hasil Purbowati et al.(2008), dengan ratarata konsumsi energi sebesar 12,8 $\pm 1,1$ $\mathrm{MJ} /$ hari. Hal ini dikarenakan kandungan energi pakan dan kebutuhan energi ternak berdasar bobot badan pada penelitian ini lebih tinggi daripada kandungan pakan pada penelitian Purbowati et al. (2008) yaitu sebesar 14,49 $\pm 0,26 \mathrm{MJ} / \mathrm{g}$. Keadaan tersebut sesuai dengan Kearl (1982) bahwa kebutuhan energi pakan akan meningkat seiring meningkatnya bobot badan ternak. 


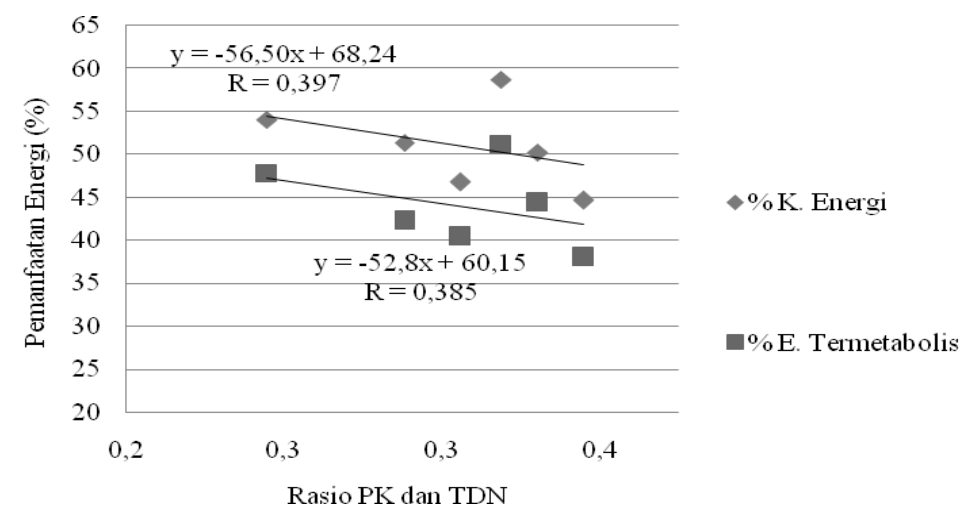

Gambar 1. Korelasi Rasio PK dan TDN Pakan dengan Pemanfaatan Energi.

\section{Energi Tercerna}

Hasil energi tercerna pada penelitian ini dapat dilihat pada Tabel 4. Pengaruh imbangan PK dan TDN pakan yang berbeda pada jumlah energi yang tercerna pada setiap perlakuan tidak berbeda nyata $(\mathrm{P}>0,05)$. Hal ini diduga kecepatan aliran digesta dan jumlah energi yang dikonsumsi setiap perlakuan tidak berbeda. Dinyatakan oleh Arora (1995), bahwa keseragaman konsumsi dan palatabilitas pakan menyebabkan kesamaan dalam kecepatan aliran digesta. Kecepatan aliran digesta diartikan sebagai waktu untuk mengeleminasi 5-80\% partikel residu pakan tidak tercerna ke dalam feses.

Selisih antara jumlah zat pakan yang dikonsumsi dan yang dieksresikan dalam feses tidaklah selalu berarti sama dengan jumlah zat makanan yang tercerna oleh ruminansia (Arora, 1995). Apabila dilihat dari hasil pengamatan, pengaruh imbangan PK dan TDN yang berbeda pada pakan perlakuan terhadap kecernaan energi pada domba lokal jantan dari semua perlakuan tidak berbeda nyata. Secara deskriptif, kecernaan tertinggi diperoleh pada perlakuan T6 $(58,74 \%)$, kemudian diikuti oleh T2 $(54,04 \%), \mathrm{T} 4(51,39 \%), \mathrm{T} 3(50,27 \%), \mathrm{T} 1$ $(46,75 \%)$, dan T5 (44,63\%). Hal ini dimungkinkan karena konsumsi serat kasar pada setiap perlakuan berbeda $(\mathrm{P}<0,05)$, sehingga menyebabkan perbedaan TDN pakan yang mencerminkan kecernaan energi. Dinyatakan oleh Yanti et al. (2004) bahwa semakin banyak konsumsi serat kasar akan menurunkan kecernaan. Rata-rata kecernaan energi dalam penelitian ini adalah $50,97 \pm 5,07 \%$.

Berdasar penelitian Purbowati et al. (2008), rasio PK dan TDN pakan 0,31 dapat menurunkan kecernaan daripada rasio 0,28. Artinya, terdapat korelasi negatif antara rasio PK dan TDN dengan kecernaan. Hasil penelitian ini sejalan dengan penelitian Purbowati et al. (2008). Hubungan antara rasio PK dan TDN pakan dengan kecernaan energi pada penelitian ini berkorelasi negatif (Gambar 1).

\section{Energi Termetabolis}

Hasil analisis statistik menunjukkan bahwa energi termetabolis antar perlakuan tidak berbeda nyata $(\mathrm{P}>0,05)$. Rata-rata energi termetabolis pada domba lokal dalam penelitian ini adalah $6,28 \pm 0,9 \mathrm{MJ} / \mathrm{hari}$ (setara dengan $44,02 \pm 0,05 \%$ dari total konsumi energi). Hal ini dikarenakan jumlah energi tercerna dan energi urin pada setiap perlakuan tidak berbeda nyata. Dinyatakan oleh Gatenby (1986) jumlah energi tercerna dan energi urin mempengaruhi energi termetabolis.

Persentase energi termetabolis pada perlakuan tidak berbeda nyata $(\mathrm{P}>0,05)$. Secara deskriptif, perlakuan T6 mempunyai presentase energi termetabolis paling baik daripada perlakuan T2, T3, T4, T1, dan T5. Hal ini dikarenakan energi yang terbuang melalui gas metan pada perlakuan T6 dan T2 relatif lebih rendah, dan kecernaan energi 
pada perlakuan T6 lebih besar dari perlakuan lainnya. Berdasar penelitian Purbowati et al. (2008), rasio PK dan TDN pakan 0,31 dapat menurunkan persentase energi termetabolis daripada rasio 0,28. Artinya, terdapat korelasi negatif antara rasio PK dan TDN dengan persentase energi termetabolis. Hasil penelitian ini sejalan dengan penelitian Purbowati et al. (2008). Hubungan antara rasio PK dan TDN pakan dengan persentase energi termetabolis pada penelitian ini berkorelasi negatif (Gambar 1.)

\section{SIMPULAN}

Imbangan PK dan TDN pakan yang berbeda pada penelitian ini tidak memberikan pengaruh terhadap pemanfaatan energi domba lokal. Pengkajian lebih lanjut seberapa besar energi yang mampu dimanfaatkan oleh ternak yang diberi pakan dengan imbangan PK dan TDN yang berbeda, sangat diperlukan.

\section{UCAPAN TERIMA KASIH}

Ucapan terima kasih dari penulis kepada Ibu drh. Sri Mawati atas bantuan finansial yang diberikan selama penelitian. Kepada komunitas Potong Mania Fapet Undip dan Beasiswa Unggulan BPKLN.

\section{DAFTAR PUSTAKA}

Arora, S.P. 1995. Pencernaan Mikrobia pada Ruminansia. Gadjah Mada University Press, Yogyakarta. (Diterjemahkan oleh R. Murwarni).

Devendra, C. and G.B. McLeroy. 1982. Goat and Sheep Production in the Tropics. ELBS Reprinted Edition. Longman Singapore Publisher Pte. Ltd., Singapore.

Gatenby, R.M. 1986. Sheep Production in the Tropics and Sub-Tropics. Longman Inc., New York.

Ginting, S.P. 2005. Sinkronisasi degradasi protein dan energi dalam rumen untuk memaksimalkan produksi protein mikroba. WARTAZOA 15 (1):1-10.
Kawashima, T., W. Sumamal, F.Terada and M. Shibata. 2001. Respiration trial system using ventilated flow-through method with facemask. JIRCAS Journal 9:53-74.

Kearl, L.C. 1982. Nutrient Requirments of Ruminants in Develpoing Countries. International Feedstuffs Institute Utah Agricultural Experimen Station Utah State University, Logan Utah.

Lestari, C.M.S., R. Adiwinarti dan Kustiyani. 2003. Penggunaan pakan konvensional untuk penggemukan domba. J. Pengembangan Peternakan Tropis. Special Edition October 2003. Hal:136141.

Mubarok, M.S. 2008. Pemanfaatan Energi Pakan pada Domba dengan Pakan Komplit dari Berbagai Limbah Pertanian dan Argoindustri. Skripsi. Program Studi Produksi Ternak. Fakultas Peternakan Universitas Diponegoro, Semarang.

Parakkasi, A. 1999. Ilmu Nutrisi dan Makanan Ternak Ruminan. Universitas Indonesia Press, Jakarta.

Pond, W.G., D.C. Church and K.R. Pond.1995. Basic Animal Nutrition and Feeding. $4^{\text {th }}$ Edition. John Wiley \& Sons, New York.

Purbowati, E., C.I. Sutrisno, E. Baliarti, S.P.S. Budhi, dan W. Lestariana. 2008. Pemanfaatan energi pakan komplit berkadar protein-energi berbeda pada domba lokal jantan yang digemukkan secara feedlot. J. Pengembangan Peternakan Tropis. 33 (1). Hal : 59-65.

Soeparno. 2005. Ilmu dan Teknologi Daging. Gadjah Mada University Press, Yogyakarta.

Steel, R.G.D. and J.H. Torrie. 1991. Prinsip dan Prosedur Statistika. Edisi Kedua. PT Gramedia Pustaka, Jakarta (Diterjemahkan oleh B. Sumantri)

Tillman, A.D., H. Hartadi, S. Reksohadiprodjo, S. Prawirokusumo dan S. Lebdosoekojo. 1984. Ilmu Makanan Ternak Dasar. Cetakan ke-5. Gadjah Mada University Press, Yogyakarta.

Yanti, Y., A. Purnomoadi, J.A. Prawoto dan E. Rianto. 2004. Konversi energi pada sapi peranakan ongole dan peranakan limousin jantan dengan pakan rumput raja dan ampas bir. J. Indon. Trop. Anim. Agric. Special Edition. Buku 1 Oktober 2004. Hal : 86-90. 